\title{
Original Research \\ Regulation of macrophage-associated inflammatory responses by species-specific lactoferricin peptides
}

\author{
Alicia Malone ${ }^{1, \dagger}$, Rikki F. Clark ${ }^{2, \dagger}$, David W. Hoskin ${ }^{1,3,4}$, Melanie R. Power Coombs ${ }^{2,3, *}$ \\ ${ }^{1}$ Department of Microbiology and Immunology, Dalhousie University, Halifax, NS B3H 4H7, Canada \\ ${ }^{2}$ Biology Department, Acadia University, Wolfville, NS B4P 2R6, Canada \\ ${ }^{3}$ Department of Pathology, Dalhousie University, Halifax, NS B3H 4H7, Canada \\ ${ }^{4}$ Department of Surgery, Dalhousie University, Halifax, NS B3H 4H7, Canada \\ *Correspondence: melanie.coombs@acadiau.ca (Melanie R. Power Coombs) \\ $\dagger$ These authors contributed equally. \\ Academic Editor: Graham Pawelec \\ Submitted: 1 November 2021 Revised: 7 December 2021 Accepted: 17 December 2021 Published: 24 January 2022
}

\begin{abstract}
Background: Inflammation is the body's response to injury or infection and is important for healing and eliminating pathogens; however, prolonged inflammation is damaging and may lead to the development of chronic inflammatory disorders. Recently, there has been interest in exploiting antimicrobial peptides (AMPs) that exhibit immunoregulatory activities to treat inflammatory diseases. Methods: In this study, we investigated the immunomodulatory effects of lactoferrin-derived lactoferricin AMPs from three different species (bovine, mouse, and human) with subtle differences in their amino acid sequences that alter their antimicrobial action; to our knowledge, no other studies have compared their immunomodulatory effects. Macrophages, key players in the induction and propagation of inflammation, were used to investigate the effects of species-specific lactoferricin peptides on inflammatory processes. Results: Bovine lactoferricin was the only one of the three peptides studied that downregulated lipopolysaccharide (LPS)-induced pro-inflammatory cytokines, tumor necrosis factor (TNF)- $\alpha$ and interleukin (IL)-6, in both human and mouse macrophages. Lactoferricin regulated inflammation through targeting LPS-activated nuclear factor (NF)- $\kappa \mathrm{B}$ and mitogen-activated protein kinase (MAPK) signaling pathways. Although the immunoregulatory role of lactoferricin during an inflammatory response in vivo is yet to be elucidated, further investigation with the use of animal models is warranted by the current findings. Conclusions: The ability of lactoferricin, especially that of bovine origin, to downregulate macrophage-mediated inflammatory responses suggests potential for the development of this peptide as a novel immunotherapeutic agent in the treatment of chronic inflammatory conditions.
\end{abstract}

Keywords: Lactoferricin; Antimicrobial peptide; Macrophage; Cytokine; Inflammation; Lipopolysaccharide

\section{Introduction}

Inflammation is the body's innate response to invading pathogens or tissue trauma. Tissue macrophages, one of the immune system's most prevalent cytokine producers detect stress signals or pathogen-associated molecular patterns (PAMPs) such as lipopolysaccharides (LPS) during the early onset of infection and release a variety of proinflammatory mediators that include tumor-necrosis factor (TNF)- $\alpha$, interleukin (IL)-1 $\beta$, IL-6, and nitric oxide (NO) [1]. This further promotes the recruitment and activation of leukocytes via signaling pathways including the nuclear factor-kappa B (NF- $\kappa$ B) pathway and the mitogen-activated protein kinase (MAPK) pathway [2-4]. Macrophages also play a key role in resolution of inflammation and restoration of tissue homeostasis [5,6]. However, when such regulatory mechanisms fail, unresolved chronic inflammation becomes harmful to the host and can lead to diseases such as colitis, sepsis, and cancer $[7,8]$.

The lactoferrin-derived antimicrobial peptide (AMP), lactoferricin, is of particular interest in the development of immunotherapeutic agents to help combat inflammatory diseases and related conditions. Lactoferrin, which yields the pepsin-cleavage product lactoferricin [9-12], is found in exocrine secretions including bile, saliva, and tears, as well as in the secondary granules of neutrophils, which can be released during an inflammatory response [13]. Lactoferrin and lactoferricin peptides can act as immunomodulatory agents with the ability to suppress in vitro and in vivo pro-inflammatory responses. Bovine lactoferrin attenuates a pro-inflammatory response induced by microorganisms $[14,15]$. One study that examined an inflammatory response mediated by THP-1 monocytes shows that bovine lactoferrin downregulates LPS-stimulated TNF- $\alpha$ cytokine production in a NF- $\kappa$ B-dependent manner [16]. Studies of human lactoferrin show the significance of this peptide as an anti-inflammatory agent $[15,17]$.

Bovine lactoferricin is an effective anti-inflammatory and anti-catabolic agent, mitigating the production of the pro-inflammatory mediators IL-6 and inducible nitric oxide synthase (iNOS) in human chondrocytes [18]. In vitro and ex vivo evidence shows that lactoferricin is an important down-regulator of LPS-induced inflammation in nucleus pulposus cells derived from the intervertebral disc 
Table 1. Amino acid sequences of bovine, mouse, and human lactoferricin.

Lactoferricin Amino acid sequence

Bovine $\quad \mathrm{NH}_{2}$-PHE-LYS-CYS-ARG-ARG-TRP-GLN-TRP-ARG-MET-LYS-LYS-LEU-GLY-ALA-PRO-SER-ILE-THR-CYSVAL-ARG-ARG-ALA-PHE-COOH

Mouse $\quad \mathrm{NH}_{2}$-GLU-LYS-CYS-LEU-ARG-TRP-GLN-ASN-GLU-MET-ARG-LYS-VAL-GLY-GLY-PRO-PRO-LEU-SER-CYSVAL-LYS-LYS-SER-SER-COOH

Human $\quad \mathrm{NH}_{2}$-THR-LYS-CYS-PHE-GLN-TRP-GLN-ARG-GLN-MET-ARG-LYS-VAL-ARG-GLY-PRO-PRO-VAL-SER-CYSILE-LYS-ARG-ASP-SER-COOH

The 25-amino acid residue sequence of lactoferricin from bovine, mouse, or human origin. Highlighted residues (in bold) represent the presence of a disulfide bond that exists between two cysteine residues in each peptide. Lactoferricin peptides used in this study were synthesized in a linear configuration. Adapted from Vorland et al. [22].

[19]. Bovine lactoferricin also inhibits the production of IL-6 by THP-1 monocytes more strongly than its parent peptide [20]. Interestingly, bovine lactoferricin also upregulates anti-inflammatory cytokines IL-10, IL-11, and IL-4 [18]. There is evidence that lactoferricin exerts its antiinflammatory effects in an extracellular signal-regulated kinase (ERK)- and p38 MAPK-dependent manner [18,21].

Lactoferricin peptides demonstrate a wide variety of immunomodulatory and anti-cancer properties; however, few studies have addressed their influence on a macrophage-associated inflammatory response, and no investigations have addressed the possible differential efficacies of lactoferricin derived from different species. Macrophages are a primary source of cytokines at the site of inflammation, thus making them an ideal cell model for studying inflammation and possible therapeutic interventions. Given the accumulating evidence of bovine lactoferricin as an immunomodulatory agent and the most potent antimicrobial agent of different species-specific lactoferricin, it was hypothesized that this peptide would have the greatest regulatory effect on macrophage-associated inflammation when compared to mouse and human lactoferricin.

\section{Materials and methods}

\subsection{Reagents}

Bovine serum albumin (BSA), phosphate buffered saline (PBS), phenylmethylsulfonyl fluoride (PMSF), Roswell Park Memorial Institute 1640 medium (RPMI), Dulbecco's Modified Eagle's Medium (DMEM), phorbol 12-myristate 13-acetate (PMA), and Triton-X-100 were purchased from Sigma-Aldrich Canada (Oakville, ON). Fetal bovine serum (FBS), 10,000 U/mL penicillin/10,000 $\mu \mathrm{g} / \mathrm{mL}$ streptomycin solution, and 1M 4-(2-hydroyethyl)1piperazineethanesulfonic acid (HEPES) buffer solution were obtained from Invitrogen Canada (Oakville, ON). Sodium dodecyl sulfate (SDS), Tris base, and Tween-20 were acquired from Bio-Shop Canada Inc. (Burlington, ON). Ethylene diamine tetraacetic acid (EDTA) was purchased from EM 46 Industries Inc. (Hawthorne, NY). Luminata $^{T M}$ Forte Western HRP substrate were purchased from EMD Millipore (Etobicoke, ON). Bio-Rad Protein Assay Dye Reagent was obtained from Bio-Rad Laboratories Inc. (Mississauga, ON). Lactoferricin peptides $(\mathrm{HCl}$ salt) (Table 1, Ref. [22]) in a linear configuration were synthesized and purchased from American Peptide (Sunnyvale, CA).

\subsection{Antibodies}

Rabbit ( $\mathrm{Rb})$ anti-p65, $\mathrm{Rb}$ anti-phospho p44/42 MAPK (ERK1/2) (pTpY202/204), Rb anti-p44/42 MAPK (ERK1/2), Rb anti-phospho-I $\kappa \mathrm{B} \alpha$ (Ser32), Rb anti-I $\kappa \mathrm{B} \alpha$, $\mathrm{Rb}$ anti-phospho-c-Jun (Ser63), $\mathrm{Rb}$ anti-c-Jun and $\mathrm{Rb}$ anti- $\beta$-actin (horse radish peroxidase (HRP) conjugate) antibodies were all purchased from Cell Signaling Technology (Beverly, MA). HRP-conjugated donkey anti-rabbit secondary antibody was purchased from Santa Cruz Biotechnology (Santa Cruz, CA). Goat-anti-rabbit secondary antibody conjugated to Alexa Fluor ${ }^{\circledR} 488$ was obtained from Invitrogen. TNF- $\alpha$, and IL- 6 capture antibodies and biotin-conjugated detection antibodies for ELISA were purchased from eBioscience (San Diego, CA).

\subsection{Cell lines}

RAW 264.7 mouse macrophage-like cells were purchased from ATTC ® (Manassas, VA). THP-1 human monocytic-like cells were kindly provided by Dr. Brent Johnston (Dalhousie University, Halifax, NS).

\subsection{Culture medium and conditions}

THP-1 and RAW 264.7 cell lines were maintained at $37{ }^{\circ} \mathrm{C}$ in a humidified $5 \% \mathrm{CO}_{2}$ incubator and cultured in complete RPMI (cRPMI) 1640 medium. Cells were cultured in $75 \mathrm{~mm}^{2}$ tissue culture flasks (Fisher Scientific, Waltham, MA) and passaged at $80-90 \%$ confluency. RAW 264.7 cells were passaged using a $25 \mathrm{~cm}$ long cell scraper (VWR, Mississauga, ON). 


\subsection{Isolation and differentiation of mouse Bone Marrow Derived Macrophages (BMDMs)}

C57BL/6 female mice, purchased from Charles River Laboratories (Wilmington, MA), were euthanized at 8-10 weeks of age, and bone marrow was collected from the tibias by flushing with PBS (pH 7.2) making a single cell suspension. Red blood cells were lysed by hypo-osmotic shock. The remaining bone marrow cells were differentiated over $7 \mathrm{~d}$ by culturing in cRPMI containing $15 \%(\mathrm{v} / \mathrm{v})$ L929-conditioned DMEM as a source of M-CSF. After 3 $\mathrm{d}$ of culture, the cells were fed with fresh medium. At 6 $\mathrm{d}$, culture medium and non-adherent cells were removed, and the remaining cells fed with fresh medium. At $7 \mathrm{~d}$ the resulting macrophages were used in experiments.

\subsection{Cell seeding}

Both cell lines and primary cells were seeded $1 \mathrm{~d}$ prior to treatment to allow for adherence to plastic. For all cell types, cells were cultured in cRPMI. THP-1 monocytic like cells were treated with $200 \mathrm{ng} / \mathrm{mL}$ PMA in order to cause cells to differentiate into macrophages and adhere to the plate overnight prior to any additional treatment. For ELISA experiments THP-1 cells were seeded in 24-well plates at $2.5 \times 10^{5}$ cells/well in $1 \mathrm{~mL}$ of medium. Cells were plated at $6 \times 10^{5}$ cells/well in a 6 -well plate for quantitative real-time polymerase chain reaction (q-PCR) experiments. For immunofluorescent assays, cells were seeded on $10 \mathrm{~mm}$ glass coverslips placed in a 12 -well plate at 1.5 $\times 10^{5}$ cells/well in $1 \mathrm{~mL}$ medium. Once adhered, cells were cultured overnight in serum-free medium to allow for cell growth arrest. For western blot experiments, cells were seeded at $1 \times 10^{6}$ cells in $75 \mathrm{~mm}^{2}$ tissue culture flasks and left for $36-48 \mathrm{~h}$ until $90 \%$ confluency was reached, then cells were treated with $200 \mathrm{ng} / \mathrm{mL}$ PMA overnight and serum-starved an additional night prior to treatment. For ELISA experiments, RAW 264.7 cells were seeded in 24well plates at $1.5 \times 10^{5}$ cells/well in $1 \mathrm{~mL}$ of medium. Cells were plated at $2.5 \times 10^{5}$ cells/well in a 6 -well plate for qPCR. For western blot experiments cells were seeded at $1 \times$ $10^{6}$ cells/well in $10 \mathrm{~cm}^{2}$ cell culture plates (Thermo Fisher) and left for 36-48 h until $90 \%$ confluency was reached, then they were serum-starved overnight prior to treatment. For immunofluorescent assays, cells were seeded on $10 \mathrm{~mm}$ glass coverslips placed in a 12 -well at $1 \times 10^{5}$ cells/well in $1 \mathrm{~mL}$ medium. BMDMs were seeded in 24-well plates at $2.5 \times 10^{5}$ cells/well in $1 \mathrm{~mL}$ of medium. Cells were plated at $6 \times 10^{5}$ cells/well in a 6 -well plate for q-PCR experiments.

\subsection{Enzyme-linked immunosorbent assay}

Supernatants were collected from THP-1, RAW 264.7, and BMDM cell cultures for detection of TNF- $\alpha$, and IL6 using a sandwich enzyme-linked immunosorbent assay (ELISA) Ready-SET-Go!® ELISA kit from eBioscience (San Diego, CA) according to the manufacturer's instruc- tions. Cells were treated with medium alone, $100 \mathrm{ng} / \mathrm{mL}$ LPS alone, or with LPS in combination with $5 \mu \mathrm{M}$ lactoferricin peptides (bovine, mouse, human). A subset of experiments used cadmium chloride $\left(\mathrm{CdCl}_{2}\right)$, purchased from Sigma Aldrich. For these experiments, cells were treated with medium alone, $10 \mu \mathrm{M} \mathrm{CdCl}_{2}$ alone, or with $\mathrm{CdCl}_{2}$ in combination with $5 \mu \mathrm{M}$ lactoferricin peptides. Supernatants being analyzed for TNF- $\alpha$ were collected after 6 $\mathrm{h}$, and all other supernatants were collected after $24 \mathrm{~h}$ of treatment. Previous experiments indicated peak cytokine expression at these time-points after LPS-stimulation of macrophages. The absorbance values at $450 \mathrm{~nm}$ were determined using a ELx800 UV universal microplate reader (BioTek Instruments, Winooski, VT), Digiread software, and SOFTmax ${ }^{\circledR}$ PRO software (version 4.3; Molecular Devices Corp., Sunnyvale, CA).

\subsection{Griess assay}

Supernatants were collected from RAW 264.7 cells and BMDMs for detection of nitrite in solution as an indicator of NO production using Griess reagent purchased from Sigma Aldrich, as per the manufacturer's instructions. Cells were seeded in a 24-well plate and left overnight. Cells were then treated with $500 \mathrm{ng} / \mathrm{mL}$ of LPS alone or with LPS in combination with $5 \mu \mathrm{M}$ lactoferricin (bovine, mouse, or human) for $24 \mathrm{~h}$. Supernatants were then collected and added to an equal volume of Griess reagent in a 96-well plate. Sodium nitrite purchased from Sigma Aldrich was used to make a standard curve. Plates were then incubated at room temperature in the absence of light. Absorbance values at $570 \mathrm{~nm}$ were determined using a ELx800 UV universal microplate reader (BioTek Instruments, Winooski, VT), Digiread software, an d SOFTmax ${ }^{\circledR}$ PRO software (version 4.3; Molecular Devices Corp., Sunnyvale, CA).

\section{9 cDNA synthesis}

Previous experiments established that peak cytokine mRNA expression occurred $4 \mathrm{~h}$ after LPS-stimulation of macrophages. RNA was harvested using a RNeasy Mini Kit purchased from Qiagen (Valencia, CA) and stored at -80 ${ }^{\circ} \mathrm{C}$ for the purpose of cDNA synthesis. Approximately 500 ng RNA was then reverse transcribed using an iScript ${ }^{T M}$ cDNA synthesis kit (Bio-Rad Laboratories; Hercules, CA) according to the manufacturer's instructions. The iScript reaction mix $(2 \mu \mathrm{L})$ and iScript reverse transcriptase $(0.5$ $\mu \mathrm{L}$ ) was added to RNA template and nuclease-free water to a final volume of $10 \mu \mathrm{L}$ and final concentration of RNA template $50 \mathrm{ng} / \mu \mathrm{L}$. The reaction was incubated in a BioRad T100 ${ }^{T M}$ Thermocycler using the following reaction protocol: $5 \mathrm{~min}$ at $25^{\circ} \mathrm{C}, 30 \mathrm{~min}$ at $42{ }^{\circ} \mathrm{C}$, and $5 \mathrm{~min}$ at 85 ${ }^{\circ} \mathrm{C}$. Once synthesized, the cDNA was stored at $-20{ }^{\circ} \mathrm{C}$ for future use. 


\subsection{Quantitative real-time Polymerase Chain Reaction}

SsoFast EvaGreen ${ }^{T M}$ Supermix ${ }^{\circledR}$ (Bio-Rad Laboratories) was used for the q-PCR. The cDNA samples were diluted 1:4 in pyrogen-free water. Primers were optimized (data not shown) before primer mixes of $100 \mathrm{nM}$ for glyceraldehyde-3phosphate dehydrogenase (GAPDH), TNF- $\alpha$, and iNOS (Table 2) (Integrated DNA Technologies; Skokie, IL) were made from $10 \mu \mathrm{L}$ of both the forward and reverse primers added to $80 \mu \mathrm{L}$ of water. A 1 $\mu \mathrm{L}$ sample of diluted cDNA was then added to a master mix solution containing $5 \mu \mathrm{L}$ EvaGreen Supermix, $3 \mu \mathrm{L}$ pyrogen-free water, and $1 \mu \mathrm{L}$ primer mix in a final volume of $10 \mu \mathrm{L}$. Negative controls did not contain any cDNA. Reactions were conducted in triplicate using a Stratagene Mx3005p q-pcr system (Agilent Technologies, Santa Clara, CA) and a Rotor-Gene 6000 q-PCR machine (Qiagen, Valencia, CA). Cycling conditions consisted of a $30 \mathrm{~s}$ activation step at $95{ }^{\circ} \mathrm{C}$, followed by 40 amplification cycles for $5 \mathrm{~s}$ at $95^{\circ} \mathrm{C}$ and $30 \mathrm{~s}$ at an annealing temperature specific to each primer set used (refer to Table 2). To confirm that the PCR reaction had produced the specific and intended products, a melt curve analysis was conducted using MxPro qPCR Software (Agilent Technologies, Santa Clara, CA) cycle threshold (CT) values, indicating the number of cycles it takes for the fluorescent signal to surpass the background fluorescence. The relative amounts of amplicons were determined by normalizing the CT values of the target gene to the endogenous control, GAPDH. These values were then normalized to the untreated control values, giving the expression fold values.

Table 2. Human and mouse primer sequences used for q-PCR experiments.

\begin{tabular}{ll}
\hline \multicolumn{2}{l}{ Human primers Primer sequence } \\
\hline GAPDH & F-5'CAACGGATTTGGTCGTATTGG-3' \\
& R-5'GGCAACAATATCCACTTTACCAGAGT-3' \\
\hline TNF- $\alpha$ & $\begin{array}{l}\text { F-5'CCAGGCAGTCAGATCATCTTCTC-3' } \\
\text { R-5'AGCTGGTTATCTCTCAGCTCCAC-3' }\end{array}$ \\
\hline Mouse primers & \\
\hline \multirow{2}{*}{ GAPDH } & F-5'CCACTTCAACAGCAACTCCCACTCTTC-3' \\
& R-5'TGGGTGGTCCAGGGTTTCTTACTCCTT-3' \\
\hline \multirow{2}{*}{ TNF- $\alpha$} & F-5'CATCTTCTCAAAATTCGAGTGACAA-3' \\
\hline \multirow{2}{*}{ iNOS } & R-5'GCACCTCAGGGAAGAGTCTG-3' \\
& F-5'CAGCTGGGCTGTACAAACCTT-3' \\
\hline
\end{tabular}

\subsection{Western blotting}

THP-1 cells, RAW 264.7 cells, and BMDMs treated with medium only, bovine, mouse, or human lactoferricin alone [ $5 \mu \mathrm{M}$ ], LPS [100 ng/mL], or a combination of lacto- ferricin peptides and LPS were lifted from tissue culture flasks using $5 \mathrm{~mL}$ of $10 \mathrm{mM}$ EDTA and a cell scraper and collected in tubes that were centrifuged at $500 \times \mathrm{g}$ for $5 \mathrm{~min}$. Cells were lysed in ice-cold RIPA buffer (50 $\mathrm{mM}$ Tris- $\mathrm{HCl}, \mathrm{pH} 7.5,150 \mathrm{mM} \mathrm{NaCl}, 50 \mathrm{mM} \mathrm{Na} 2 \mathrm{HPO}_{4}$, $0.25 \%$ sodium deoxycholate $[\mathrm{w} / \mathrm{v}], 0.1 \%$ Nonidet $\mathrm{P}-40$ $[\mathrm{v} / \mathrm{v}], 5 \mathrm{mM}$ ethylenediaminetetraacetic acid, and $5 \mathrm{mM}$ ethyleneglycoltetraacetic acid) supplemented with protease and phosphatase inhibitors $\left(1 \mathrm{mM} \mathrm{Na} \mathrm{VO}_{4}, 1 \mathrm{mM} \mathrm{NaF}\right.$, $1 \mathrm{mM}$ phenylmethylsulfonyl fluoride, $1 \mu \mathrm{g} / \mathrm{mL}$ aprotinin, $1 \mu \mathrm{g} / \mathrm{mL}$ leupeptin, and $1 \mu \mathrm{g} / \mathrm{mL}$ pepstatin) on ice for 15 $\min$. Samples were centrifuged at $14,000 \times g$ for $10 \mathrm{~min}$ to remove cell debris. Supernatants containing protein were then collected and stored at $-80{ }^{\circ} \mathrm{C}$ for future use. A Bradford assay (Bio-Rad, Hercules, CA, United States) was used to quantify total protein concentrations from each sample. The proteins in each sample were then denatured by the addition of sample buffer (200 mM Tris- $\mathrm{HCl}$ [pH 6.8], 30\% glycerol $[\mathrm{v} / \mathrm{v}], 6 \%$ sodium dodecyl sulfate $[\mathrm{w} / \mathrm{v}], 15 \% \beta$ mercaptoethanol $[\mathrm{v} / \mathrm{v}]$, and $0.001 \%$ bromophenol $[\mathrm{w} / \mathrm{v}]$ ) and placed in a heating block at $95{ }^{\circ} \mathrm{C}$ for $5 \mathrm{~min}$. If not used immediately, samples were stored at $-80{ }^{\circ} \mathrm{C}$ until future use. Equal amounts of protein sample $(10 \mu \mathrm{g})$ were loaded onto Tris- $\mathrm{HCl}$ acrylamide resolving gels and separated by sodium dodecyl sulfate-polyacrylamide gel electrophoresis. Proteins were transferred to a nitrocellulose membrane using the iBlot ${ }^{\circledR}$ dry blotting system (Life Technologies, Burlington, ON). Membranes were washed with Tris-buffered saline (TBS)-Tween-20 (TBST; 20 mM Tris$\mathrm{HCl}$ [pH 7.6], $200 \mathrm{mM} \mathrm{NaCl}, 0.05 \%$ Tween-20 [v/v]) and blocked in TBST containing $5 \%$ fat-free milk powder $[\mathrm{w} / \mathrm{v}]$ for $1 \mathrm{~h}$ at room temperature or overnight at $4{ }^{\circ} \mathrm{C}$ with gentle rocking.

Membranes were washed and exposed to the primary antibody for $1 \mathrm{~h}$ at room temperature or overnight at $4{ }^{\circ} \mathrm{C}$ with gentle rocking. Membranes were washed and then exposed to the HRP-conjugated secondary antibody (1:1000 in TBST blocking solution) for $1 \mathrm{~h}$ at room temperature with gentle rocking. Membranes were washed and reacted with Luminata ${ }^{T M}$ Forte Western HRP Substrate (Millipore; Taunton, MA), exposed to X-ray film (Sci-Med Inc.; Truro, NS), and then developed using a Kodak X-OMAT 1000A automated X-ray developer. In order to account for any variation of loading between protein samples, membranes were re-probed for $\beta$-actin. Image Studio ${ }^{T M}$ Software (LICOR $\AA$; Guelph, ON) was used to determine the relative intensity of each band through densitometry. The ratio of actin normalized to phospho-protein was compared to that of total protein normalized to phospho-protein and subsequently normalized to the medium control.

\subsection{Immunofluorescence}

Imaging of cells stained with fluorescent antibodies was used to determine nuclear localization of the inflammation-associated transcription factor NF- $\kappa$ B. Cells 

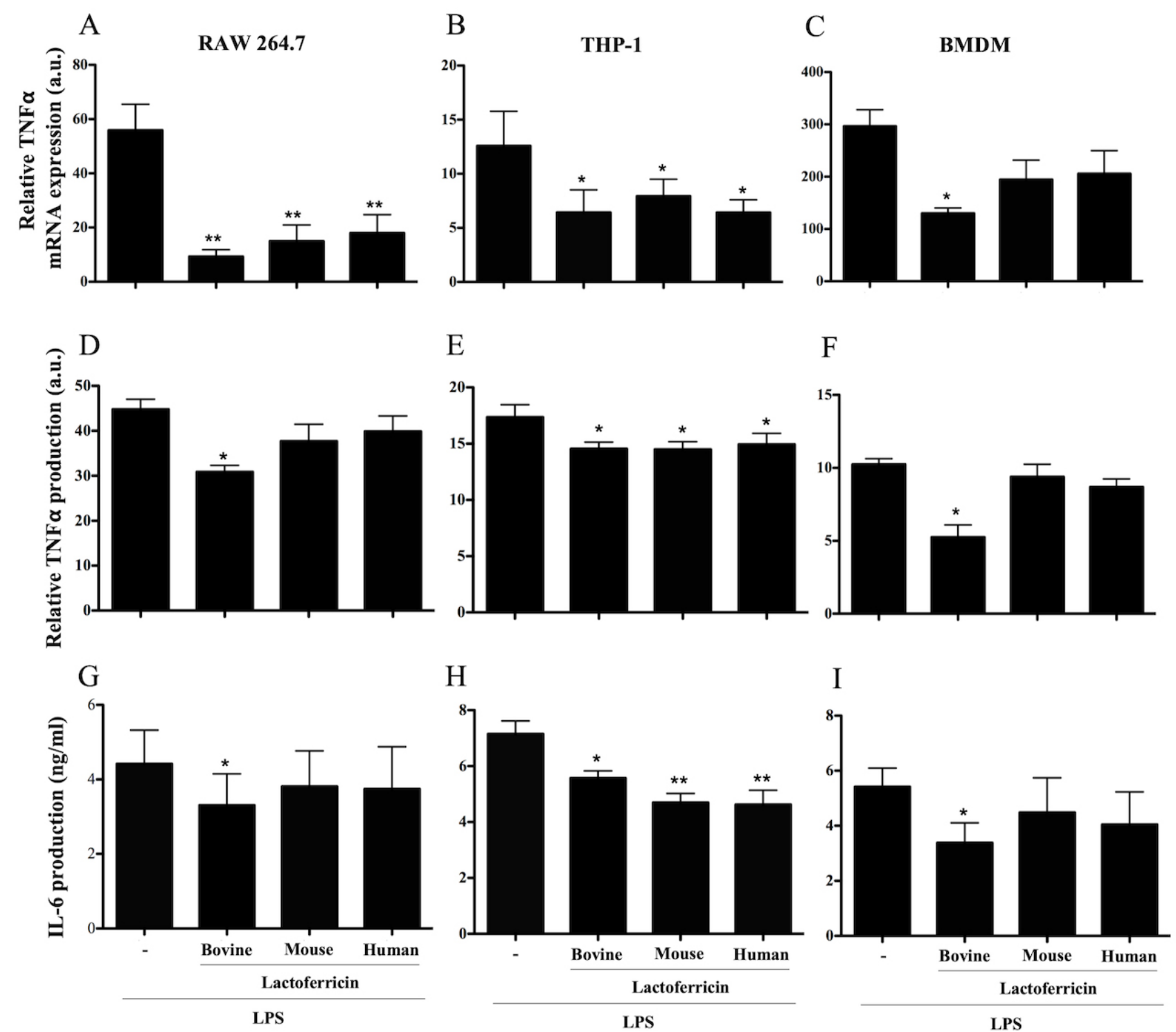

Fig. 1. Species-specific lactoferricin peptides decrease LPS-induced TNF- $\alpha$ and IL-6 cytokine production in macrophages. (A, D, and G) RAW 264.7 cells, (B, E, and H) THP-1 cells, and (C, F and I) BMDMs were treated with $100 \mathrm{ng} / \mathrm{mL}$ LPS alone or in combination with $5 \mu \mathrm{M}$ bovine, mouse, or human lactoferricin. RNA was isolated for cDNA synthesis and then qPCR was performed to determine expression levels of TNF- $\alpha, 4 \mathrm{~h}$ after treatment, relative to untreated control treatments (A-C) (calculated by dividing the expression value for the lactoferricin treated cultures by the untreated control and multiplied by 100). Supernatants were collected and used in ELISA assays to detect TNF- $\alpha$ (D-F) $6 \mathrm{~h}$ after treatment and IL-6 (G-I) $24 \mathrm{~h}$ after treatment. Levels of TNF- $\alpha$ production are relative to untreated control treatments (calculated by dividing the expression value for the lactoferricin treated cultures by the untreated control and multiplied by 100). Data are the mean of 3-4 independent experiments \pm SEM. * denotes $p<0.05$ compared to LPS positive control as determined by ANOVA with Dunnett's multiple comparisons post-test. a.u. denotes arbitrary units.

were grown on coverslips that were placed in a 12-well plate, left for $24 \mathrm{~h}$, serum-starved overnight, and treated with peptide and LPS for $4 \mathrm{~h}$. Medium was removed and cells were fixed with $4 \%$ paraformaldehyde. Coverslips were washed in PBS and allowed to dry overnight. Slides were blocked and incubated with anti-p65 antibody diluted 1:100 in antibody dilution buffer. From this point on, all incubations were performed in the absence of light. Cells were washed in PBS, incubated in goat-anti-rabbit sec- ondary antibody conjugated to Alexa Fluor ${ }^{\circledR} 488$ diluted 1:500 in antibody dilution buffer, washed again, and incubated in $30 \mu \mathrm{M}$ 4',6-diamidino-2-phenylindole (DAPI) diluted 1:100 in 1xPBS. Coverslips were lifted from the plate. Dako Fluorescent Mounting Medium was applied, and each coverslip was mounted to individual Fisherbrand Superfrost ${ }^{\circledR}$ Plus slides. Visualization of slides was done using a Zeiss Axioplan II Motorized Microscope (Zeiss Canada, North York, ON) and AxioVision 4.8 Microscopy Software. 


\subsection{Statistical analysis}

A one-way analysis of variance (ANOVA) with a Dunnett's post-test was conducted using GraphPad Prism Software (GraphPad Software Inc.; La Jolla, CA). Data were considered significantly different when the $p$ value was less than 0.05 (indicated by $*$ ); when the $p$ value was greater than 0.05 , data were considered to not be statistically significant.

\section{Results}

A sub-lethal concentration of lactoferricin peptides was used to ensure regulation of inflammatory cytokine synthesis was not due to cell stress or death. Previous studies established that a $5 \mu \mathrm{M}$ concentration of either bovine, mouse, or human lactoferricin did not affect the viability of RAW 264.7, THP-1 or BMDM cells (data not shown). This is consistent with other studies of AMPs and their immunomodulatory effects on a variety of different cells that employed peptide concentrations ranging from 1-30 $\mu \mathrm{M}$ [23-28].

\subsection{Lactoferricin peptides decrease pro-inflammatory cytokine synthesis by LPS-stimulated macrophages}

The ability of bovine, mouse and human lactoferricin peptides to downregulate pro-inflammatory cytokine mRNA expression by LPS-stimulated macrophages was investigated in a series of q-PCR experiments. A 5 $\mu \mathrm{M}$ concentration of each lactoferricin peptide dampened LPS-induced TNF- $\alpha$ mRNA expression in RAW 264.7 macrophages (Fig. 1A; $p<0.01$ ) and THP-1 macrophages (Fig. 1B; $p<0.05$ ). However, in BMDMs, only bovine lactoferricin downregulated LPS-induced TNF- $\alpha$ mRNA expression (Fig. $1 \mathrm{C} ; p<0.05$ ).

In line with the mRNA expression findings, ELISA analysis of $24 \mathrm{~h}$ culture supernatants demonstrated that 5 $\mu \mathrm{M}$ bovine lactoferricin significantly reduced the production of TNF- $\alpha$ following LPS stimulation of RAW 264.7 cells, THP-1 cells, and BMDMs comparison to LPS treatment alone (Fig. 1D-F). Mouse and human lactoferricin also decreased LPS-induced TNF- $\alpha$ production by THP-1 cells (Fig. 1E), but did not affect TNF- $\alpha$ production by LPSstimulated RAW 264.7 cells or BMDMs (Fig. 1D-F). Representative TNF- $\alpha$ concentrations from RAW 264.7 cells are as follows: no treatment, $63 \mathrm{pg} / \mathrm{mL}$; LPS alone, 3120 $\mathrm{pg} / \mathrm{mL}$; bovine lactorferricin plus LPS, $1853 \mathrm{pg} / \mathrm{mL}$.

We next asked whether lactoferricin peptides affected LPS-stimulated IL-6 production by RAW 264.7 cells, THP1 cells, and BMDMs. ELISA analysis of $24 \mathrm{~h}$ culture supernatants from LPS-stimulated RAW 264.7 cells, THP1 cells, and BMDMs that were treated with bovine lactoferricin showed a significant decrease in IL-6 production in comparison to the untreated control (Fig. 1G-I, $p<0.05$ ). Neither human nor mouse lactoferricin affected IL-6 production by LPS-stimulated RAW 264.7 cells or BMDMs. All three lactoferricin peptides decreased LPS-induced IL-
6 production by THP-1 cells (Fig. $1 \mathrm{H}, p<0.05$ ). Lactoferricin peptides had a similar effect on IL-6 mRNA expression by LPS-stimulated macrophages (data not shown). Lactoferricin treatment without LPS stimulation did not influence the production of TNF- $\alpha$ or IL- 6 by RAW 264.7 cells, THP-1 cells, or BMDMs (data not shown).

\subsection{Lactoferricin peptides decrease NO production in LPS-stimulated macrophages}

To determine if lactoferricin peptides inhibited the LPS-stimulated production of NO, RAW 264.7 cells and BMDMs were stimulated with $500 \mathrm{ng} / \mathrm{mL}$ LPS in the absence or presence of different lactoferricin peptides for $24 \mathrm{~h}$. Culture supernatants were tested for the presence of NO using Griess reagent. A significant decrease in LPS-induced NO production was observed in RAW 264.7 cells treated with either bovine or human lactoferricin (Fig. 2A, $p<$ 0.01). A decrease in NO production upon LPS-stimulation was observed with the addition of bovine, mouse, or human lactoferricin in BMDMs (Fig. 2B, $p<0.05$ ).

\subsection{Lactoferricin peptides decrease inducible NO synthase expression in LPS-stimulated macrophages}

To determine whether lactoferricin-mediated inhibition of NO was associated with decreased iNOS expression, RAW 264.7 and BMDM cells were treated with $500 \mathrm{ng} / \mathrm{mL}$ LPS alone or in combination with $5 \mu \mathrm{M}$ bovine, mouse, or human lactoferricin for $4 \mathrm{~h}$ prior to RNA isolation. Levels of iNOS expression were normalized to the LPS control since iNOS mRNA was below the level of detection in untreated cells. A significant decrease in LPS-induced iNOS mRNA expression was seen in RAW 264.7 cells treated with either bovine or human lactoferricin (Fig. 3A, $p<$ 0.05). When LPS-stimulated BMDMs were treated with either mouse or human lactoferricin there was a significant reduction in iNOS expression in comparison to LPS treatment alone (Fig. 3B, $p<0.05$ ).

\subsection{Lactoferricin peptides reduce expression of phosphorylated I $\kappa \mathrm{B} \alpha$ in LPS-stimulated macrophages}

To determine whether lactoferricin peptides influenced LPS-induced pro-inflammatory signaling cascades, RAW 264.7 and THP-1 cells were treated with LPS in the absence or presence of bovine, mouse, or human lactoferricin, and western blot analysis of cell lysates for phospho-I $\kappa \mathrm{B} \alpha$ expression was conducted. Bovine lactoferricin reduced LPS-induced phospho-I $\kappa \mathrm{B} \alpha$ expression in RAW 264.7 cells at $1 \mathrm{~h}$ but not at $30 \mathrm{~min}$ or $4 \mathrm{~h}$ (Fig. 4A). Subsequent western blot analysis was conducted after $1 \mathrm{~h}$ incubation with peptide, LPS, or LPS plus peptide. Treatment of RAW 264.7 cells with the combination of LPS and lactoferricin peptides led to a decrease in phospho-I $\kappa \mathrm{B} \alpha$ expression in comparison to LPS treatment alone, whereas treatment with peptide alone had no significant effect on phospho-I $\kappa \mathrm{B} \alpha$ expression (Fig. $4 \mathrm{~B}-\mathrm{C} p<0.01$ ). In a sim- 

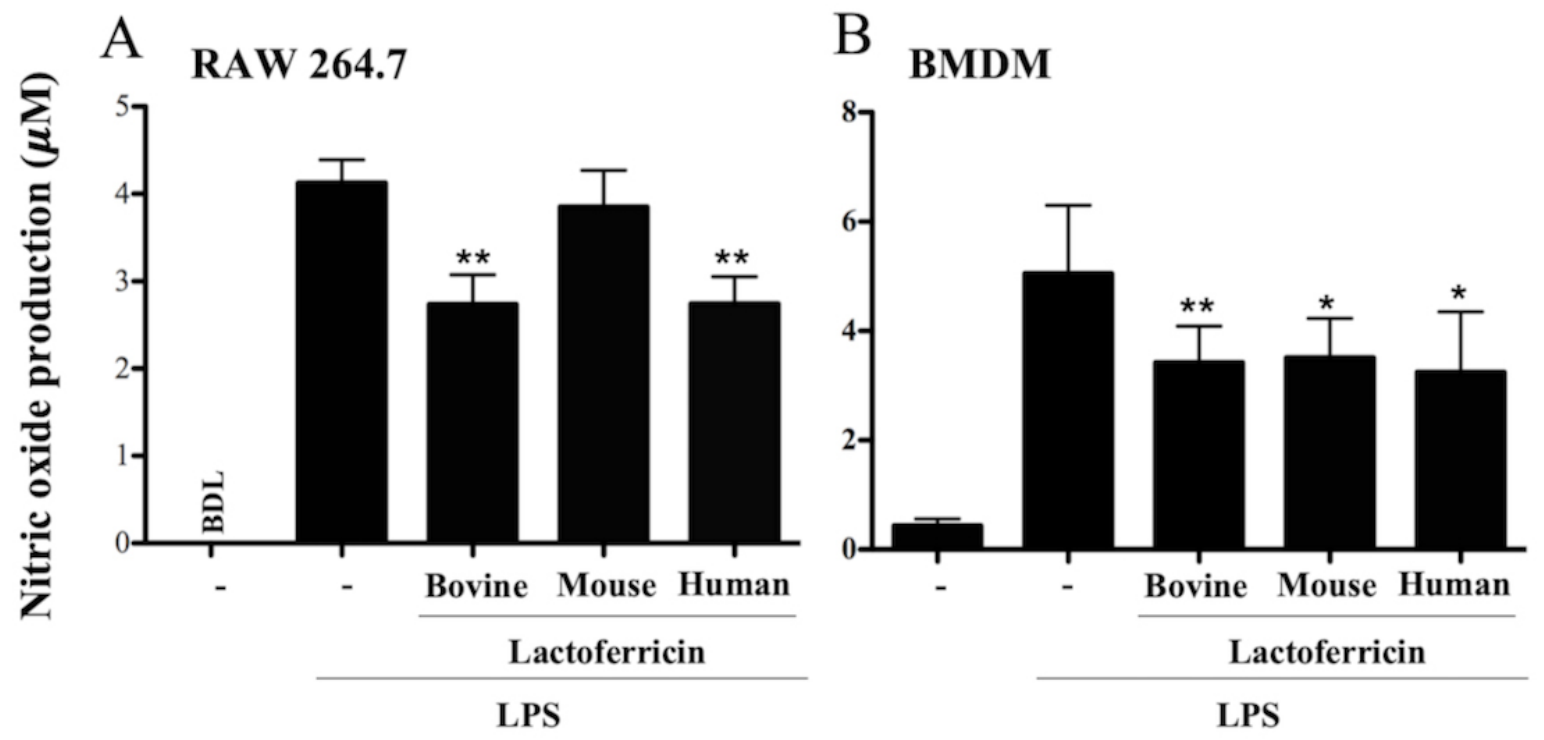

Fig. 2. Lactoferricin peptides decrease nitric oxide production in LPS-stimulated macrophages. (A) RAW 264.7 cells and (B) BMDMs were treated with $500 \mathrm{ng} / \mathrm{mL}$ of LPS alone or in combination with $5 \mu \mathrm{M}$ bovine, mouse, or human lactoferricin for $24 \mathrm{~h}$. Supernatants were collected and used in a Griess assay to measure nitric oxide production. Data are the mean of 4 independent experiments $\pm \mathrm{SEM} ; *$ denotes $p<0.05$ and ${ }^{* *} p<0.01$ compared to LPS treatment as determined by ANOVA with Dunnett's multiple comparisons post-test. BDL, below detectable levels.
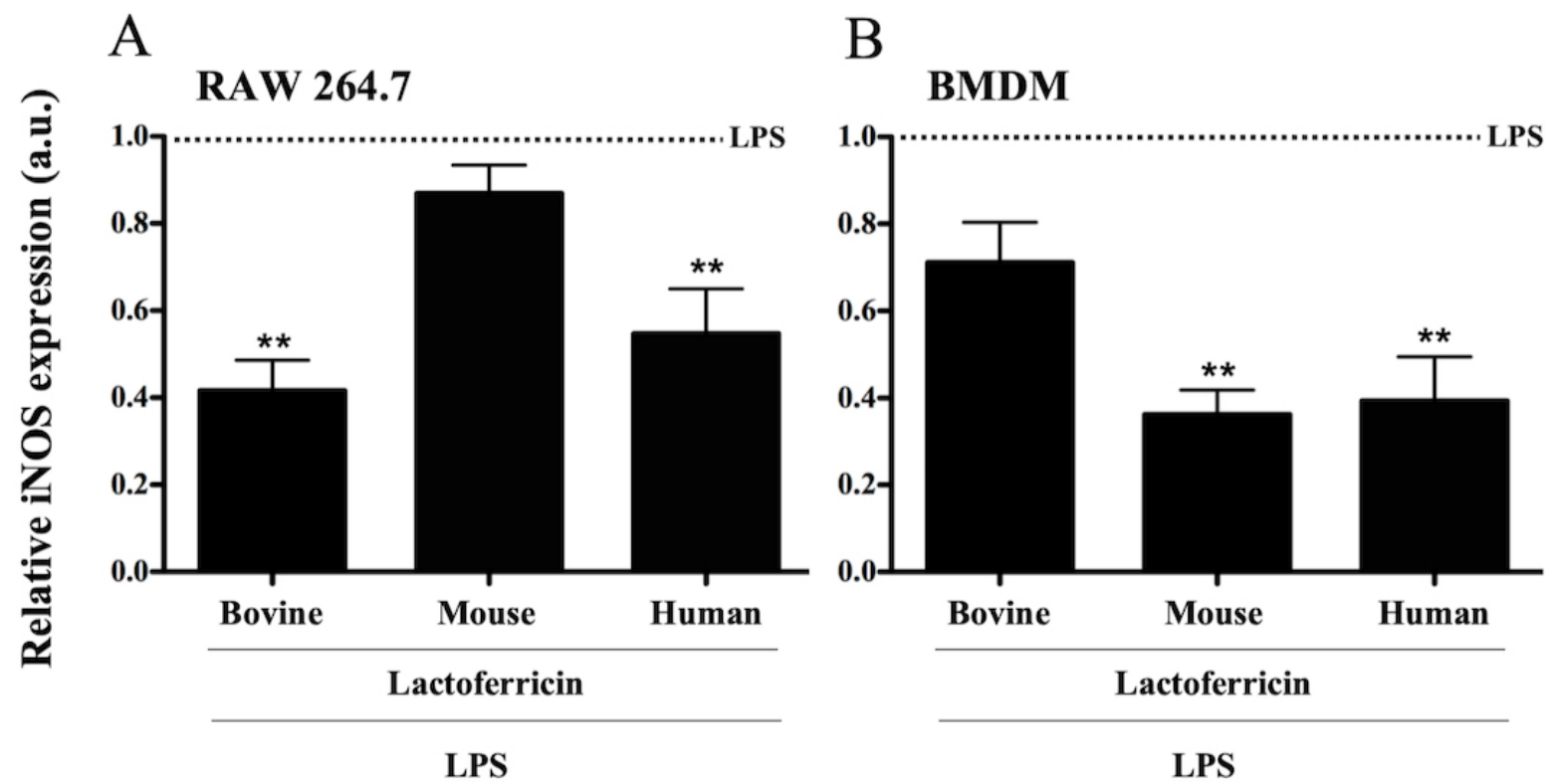

Fig. 3. Lactoferricin peptides decrease inducible nitric oxide synthase expression in LPS-stimulated macrophages. (A) RAW 264.7 cells and (B) BMDMs were treated with $500 \mathrm{ng} / \mathrm{mL}$ of LPS in combination with $5 \mu \mathrm{M}$ bovine, mouse, or human lactoferricin for $4 \mathrm{~h}$. RNA was isolated for cDNA synthesis, and qPCR was performed to determine levels of iNOS expression. Data are expressed as a relative value of LPS induced iNOS expression (iNOS in lactoferricin-treated cells divided by iNOS in cells treated with LPS alone). Data are the mean of 3 independent experiments \pm SEM; * denotes $p<0.05$ and $* * p<0.01$ compared to LPS positive control as determined by ANOVA with Dunnett's multiple comparisons post-test. a.u. denotes arbitrary units.

ilar manner to RAW 264.7 cells, there was a significant decrease in THP-1 cell expression of LPS-induced phospho$\mathrm{I} \kappa \mathrm{B} \alpha$ following treatment with bovine, mouse, or human lactoferricin (Fig. 4D-E, $p<0.01$ ).
3.5 Lactoferricin peptides inhibit the nuclear translocation of $N F-\kappa B$ in LPS-stimulated macrophages

To determine whether lactoferricin peptides inhibited the nuclear translocation of NF- $\kappa$ B, RAW 264.7 and THP- 


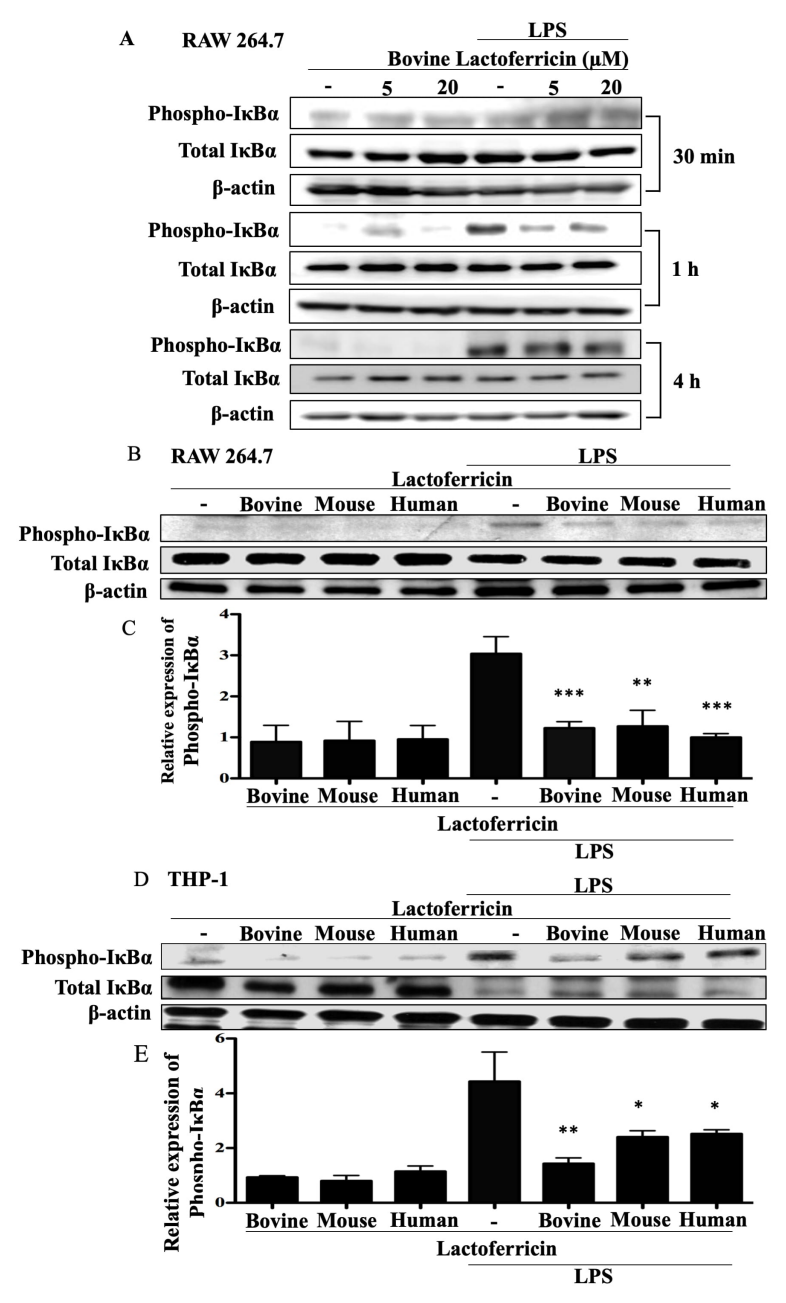

Fig. 4. Lactoferricin peptides reduce expression of phosphorylated $\mathbf{I} \kappa \mathbf{B} \alpha$ in LPS-stimulated macrophages. (A) RAW 264.7 cells were treated with the indicated concentrations of bovine lactoferricin and $100 \mathrm{ng} / \mathrm{mL}$ LPS for the indicated times. Cell lysates were collected and protein expression was determined by western blotting. Nitrocellulose membranes were probed with the indicated antibodies and corresponding secondary antibodies. Data shown are representative of two independent time-course experiments. (B), (C) RAW 264.7 and (D), (E) THP-1 cells were incubated with $100 \mathrm{ng} / \mathrm{mL}$ LPS, $5 \mu \mathrm{M}$ bovine, mouse, or human lactoferricin, or a combination of LPS and one species-specific lactoferricin peptide as indicated. Cell lysates were collected after $1 \mathrm{~h}$ and used in western blotting as described in (A). Data shown are one representative blot. (B), (D) One representative western blot and $(\mathrm{C}),(\mathrm{E})$ the mean density of phosphorylated $\mathrm{I} \kappa \mathrm{B} \alpha$ normalized to untreated controls and to total $\mathrm{I} \kappa \mathrm{B} \alpha$ and $\beta$-actin from 4 (RAW 264.7 cells) or 3 (THP-1 cells) independent experiments \pm SEM; $* *$ denotes $p<0.01$ and $* * *$ denotes $p<0.001$ compared to LPS alone treatments as determined by ANOVA with Dunnett's multiple comparisons post-test.

1 cells were treated with LPS in the absence or presence of bovine, mouse, or human lactoferricin for $1 \mathrm{~h}$ and stained

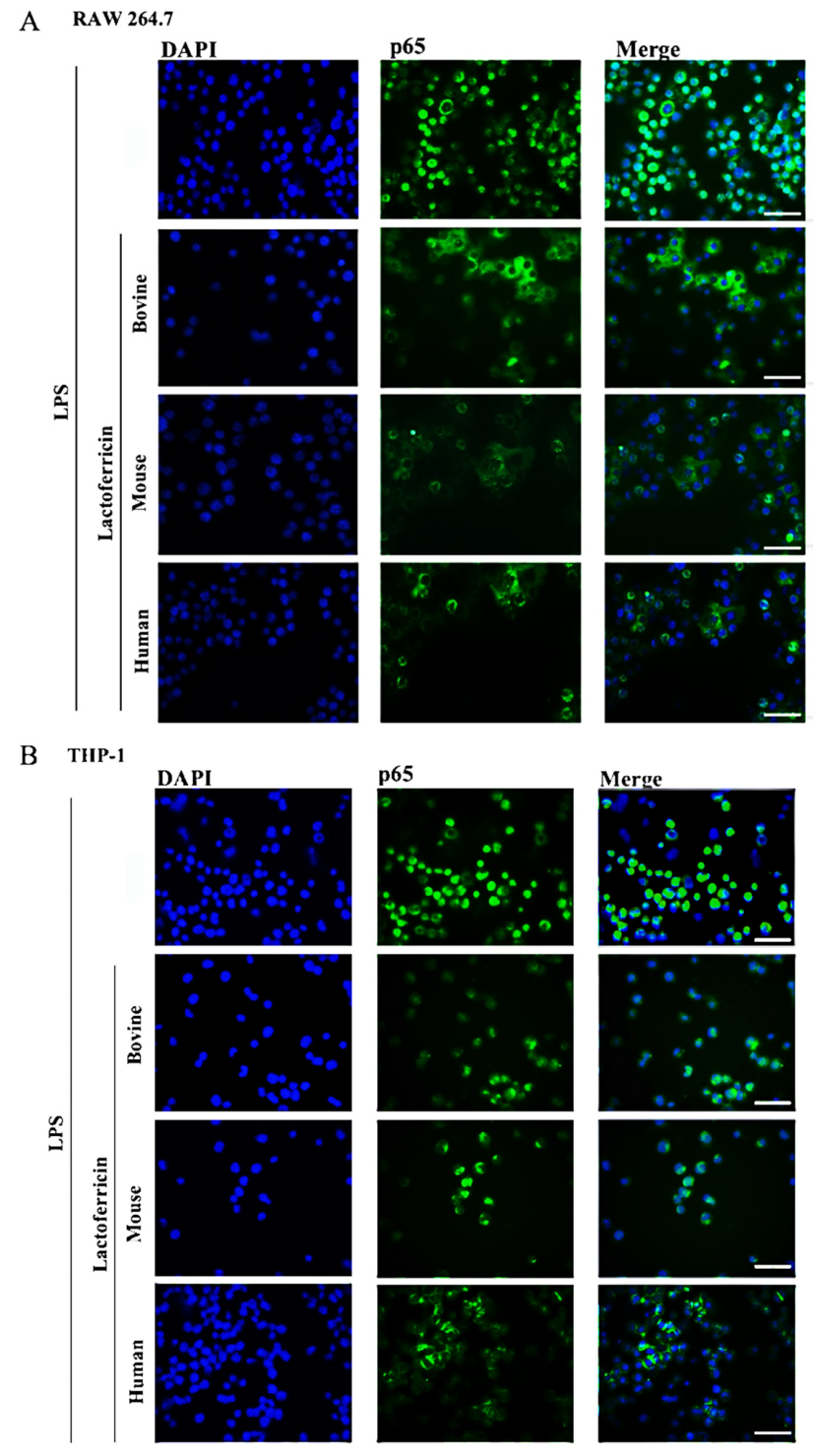

Fig. 5. Lactoferricin peptides inhibit the nuclear translocation of NF- $\kappa$ B in LPS-stimulated macrophages. (A) RAW 264.7 cells and (B) THP-1 cells were treated with $100 \mathrm{ng} / \mathrm{mL}$ LPS alone or in combination with $5 \mu \mathrm{M}$ bovine, mouse, or human lactoferricin for $1 \mathrm{~h}$. Cells were fixed and incubated with nuclear stain, DAPI $(30 \mu \mathrm{M})$, and rabbit anti-p65 antibody with secondary goatanti-rabbit Alexa Fluor 488 ( conjugate, then imaged using fluorescent microscopy. Images are representative of two independent experiments. Scale bar represents $40 \mu \mathrm{m}$.

with anti-p65 (a subunit of NF- $\kappa \mathrm{B}$ ) antibody and the nuclear stain DAPI. Cells were visualized using fluorescent microscopy. LPS stimulation of RAW 264.7 and THP-1 macrophages resulted in a prominent nuclear translocation of p65 (Fig. 5A-B). RAW 264.7 cells stimulated with LPS in the presence of bovine, mouse, or human lactoferricin showed reduced nuclear-localized p65 in comparison to the LPS-only control (Fig. 5A). Nuclear translocation of p65 in THP-1 cells was also inhibited by lactoferricin treat- 


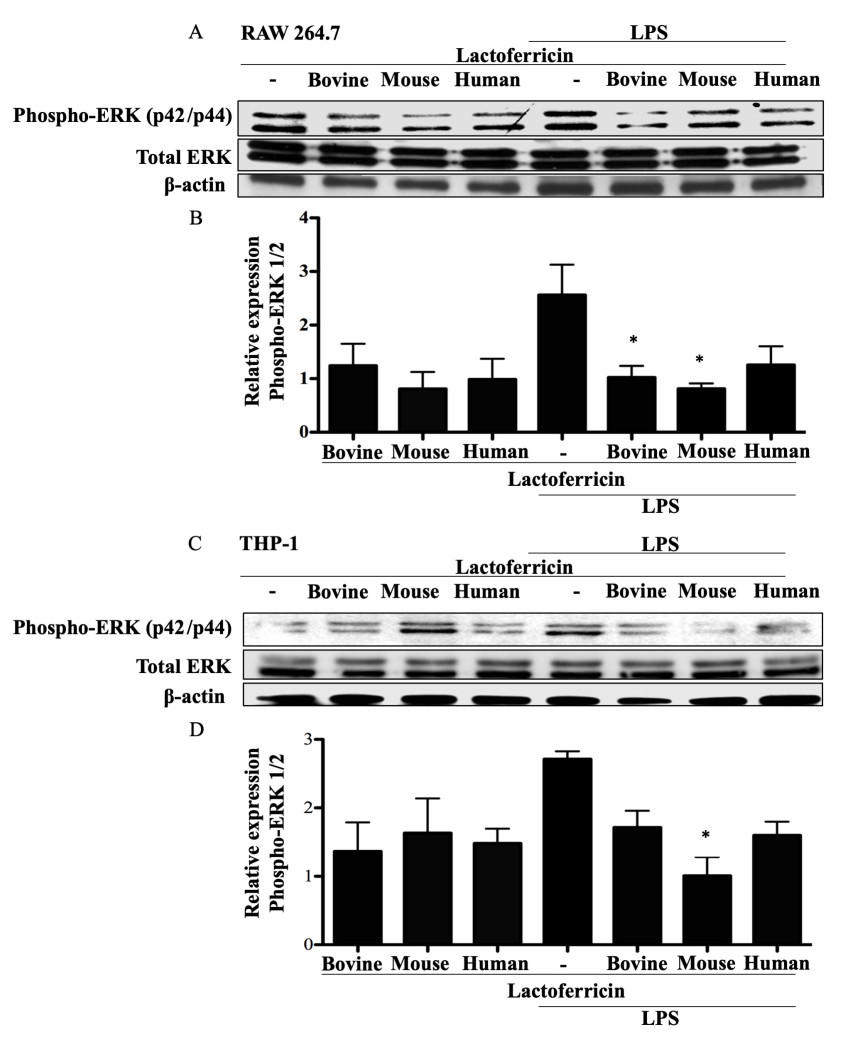

Fig. 6. Lactoferricin peptides inhibit ERK phosphorylation in LPS-stimulated macrophages. (A), (B) RAW 264.7 and (C), (D) THP-1 cells were incubated with $100 \mathrm{ng} / \mathrm{mL}$ LPS, $5 \mu \mathrm{M}$ bovine, mouse, or human lactoferricin, or a combination of LPS and one species-specific lactoferricin as indicated. Cell lysates were collected and protein expression was determined using western blotting. Nitrocellulose membranes were probed with the indicated antibodies and the appropriate secondary antibodies. (A), (C) Data shown are from one representative western blot. (B), (D) The mean density of phosphorylated ERK $1 / 2$ normalized to untreated controls and to total ERK $1 / 2$ and $\beta$-actin from 4 (RAW 264.7 cells) or 3 (THP-1 cells) independent experiments \pm SEM.

ment (Fig. 5B). Species-specific lactoferricin treatments therefore inhibited the LPS-induced translocation of NF$\kappa \mathrm{B}$ into the nucleus of mouse and human macrophages. Western blot analysis showed that lactoferricin peptides alone did not affect cytosolic p65 levels in LPS-stimulated RAW 264.7 and THP-1 macrophages in comparison to cells treated with LPS alone (data not shown).

\subsection{Lactoferricin peptides reduce ERK phosphorylation in LPS-stimulated macrophages}

To determine if lactoferricin peptides target MAPK signaling pathways, western blot analysis was conducted using lysates from RAW 264.7 and THP-1 cells treated with lactoferricin alone, LPS alone, or LPS plus lactoferricin. RAW 264.7 cells treated with either bovine or mouse lactoferricin showed a significant reduction in LPS-induced phospho-ERK $1 / 2$ expression in comparison to LPS treat-

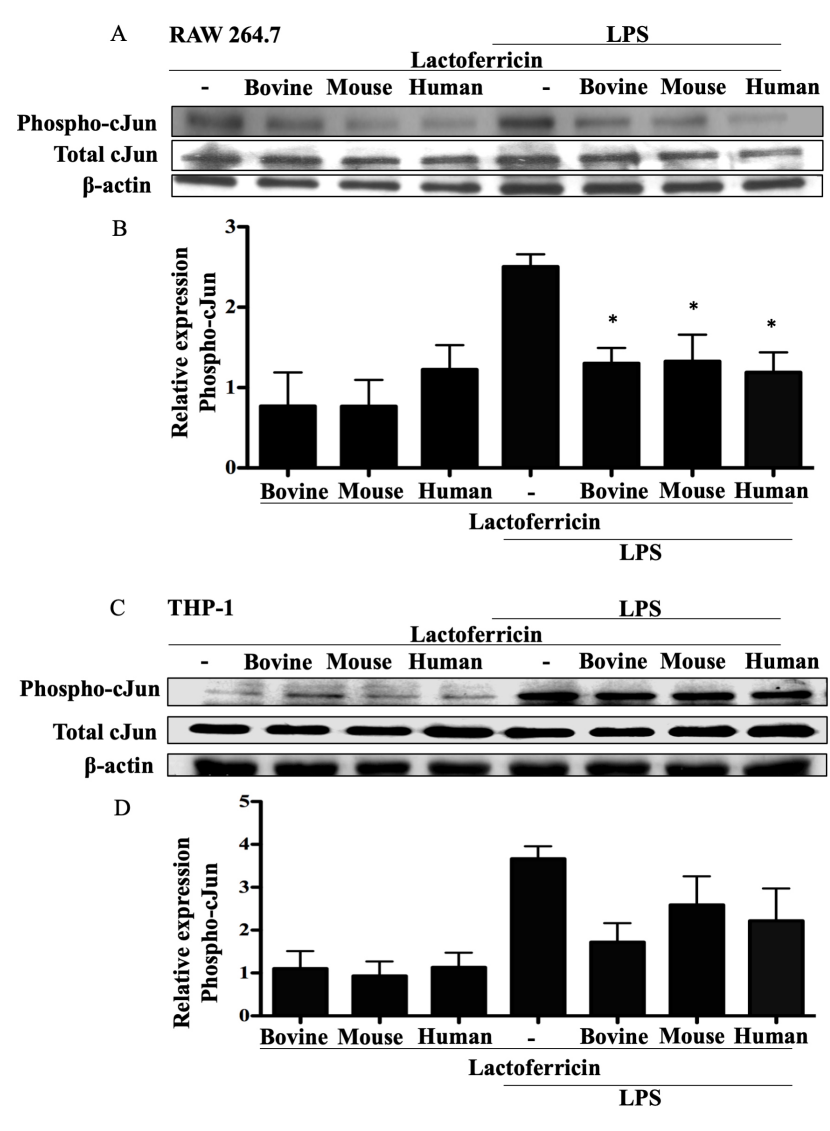

Fig. 7. Lactoferricin peptides inhibit c-Jun phosphorylation in LPS-stimulated mouse macrophages. (A), (B) RAW 264.7 and (C), (D) THP-1 cells were incubated with $100 \mathrm{ng} / \mathrm{mL}$ LPS, $5 \mu \mathrm{M}$ bovine, mouse, or human lactoferricin, or a combination of LPS and one species-specific lactoferricin peptide, as indicated. Cell lysates were collected and protein expression was determined using western blotting. Nitrocellulose membranes were probed with the indicated antibodies and the appropriate secondary antibodies. (A), (C) Data shown are from one representative western blot. (B), (D) The mean density of phosphorylated c-Jun normalized to untreated controls and to total c-Jun and $\beta$-actin from 4 (RAW 264.7 cells) or 3 (THP-1 cells) independent experiments \pm SEM.

ment alone (Fig. 6A-B, $p<0.05$ ). THP-1 cells showed a similar trend of reduced phospho-ERK $1 / 2$, demonstrating a decrease in LPS-induced ERK 1/2 expression with peptide treatment (Fig. 6C-D, $p<0.05$ ).

\subsection{Lactoferricin peptides decrease c-Jun phosphorylation in LPS-stimulated mouse macrophages}

Western blot analysis of phospho-c-Jun expression in lactoferricin-treated, LPS-stimulated RAW 264.7 cells demonstrated a significant reduction in phospho-c-Jun in comparison to cells treated with LPS alone (Fig. 7A-B, $p$ $<0.05)$. However, LPS-stimulated THP-1 macrophages treated in a similar manner did not show a significant decrease in phospho-c-Jun expression following lactoferricin treatment (Fig. 7C-D). 
3.8 Lactoferricin peptides decrease cadmium-induced $T N F-\alpha$ production in macrophages

To determine whether species-specific lactoferricin peptides were able to downregulate a pro-inflammatory response induced by a stimulus other than LPS, RAW 264.7 and THP-1 cells were treated with $\mathrm{CdCl}_{2}$ alone or in the presence of bovine, mouse, or human lactoferricin. After 24 $\mathrm{h}$, culture supernatants were collected, and ELISA was used to measure TNF- $\alpha$. As with LPS stimulation, there was a significant decrease in $\mathrm{CdCl}_{2}$-induced TNF- $\alpha$ production by THP-1 (Fig. 8A, $p<0.05$ ) and RAW 264.7 (Fig. 8B$\mathrm{C}, p<0.05)$ cells treated with bovine, mouse, or human lactoferricin. Lactoferricin peptides therefore downregulated pro-inflammatory TNF- $\alpha$ induced by nonmicrobial activation with $\mathrm{CdCl}_{2}$.

\section{Discussion}

Previous studies of AMPs have often focused on the direct antimicrobial properties of these cationic peptides; however, more recently the focus has shifted towards their direct immunomodulatory features. To our knowledge, this is the first study to demonstrate the differential immunomodulatory efficacy of species-specific lactoferricin peptides and uncover several potential mechanisms to account for inhibition of inflammatory responses by LPSstimulated macrophages. Lactoferrin released by neutrophils at sites of inflammation can be as high as $2.5 \mu \mathrm{M}$ concentration [29]. Although lactoferricin concentrations at sites of inflammation have not yet been reported in the literature, proteolytic hydrolysis of lactoferrin is predicted to generate lactoferricin at sites of inflammation, albeit at concentrations well below $2.5 \mu \mathrm{M}$.

Given that TNF- $\alpha$ is a prototypical pro-inflammatory cytokine released at the onset of inflammation, the production of this cytokine was evaluated in lactoferricin-treated macrophages. Our findings suggest that mouse and human macrophages are susceptible to the anti-inflammatory effects of lactoferricin peptides, albeit to varying degrees. Bovine lactoferricin decreased TNF- $\alpha$ production by mouse BMDMs and RAW 264.7 cells; however, mouse and human lactoferricin had no significant effect on TNF$\alpha$ production by these cells. In contrast, there was decreased LPS-induced TNF- $\alpha$ production by human THP1 cells treated with all three peptides. A similar effect was seen on the production of IL-6 by LPS-stimulated macrophages. Bovine lactoferricin consistently downregulated pro-inflammatory cytokine production in mouse and human macrophages.

Supporting the observations with pro-inflammatory cytokines, lactoferricin was also able to downregulate expression of TNF- $\alpha$ mRNA in macrophages. As before, bovine lactoferricin exhibited the most potent antiinflammatory effect, suppressing LPS-induced mRNA expression in mouse BMDMs and RAW 264.7 macrophages as well as human THP-1 macrophages. The TNF- $\alpha$ mRNA

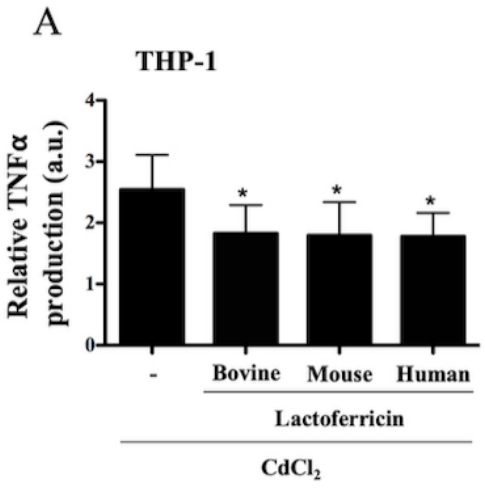

B

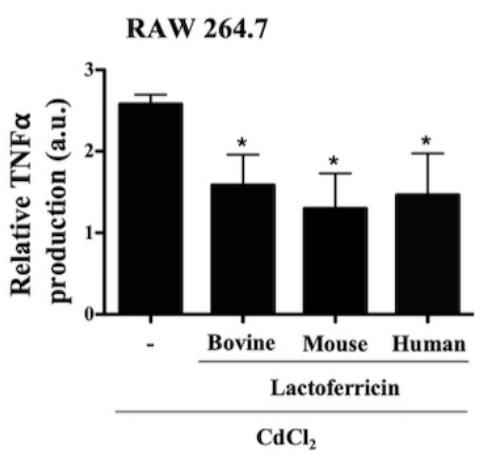

$\mathrm{C}$

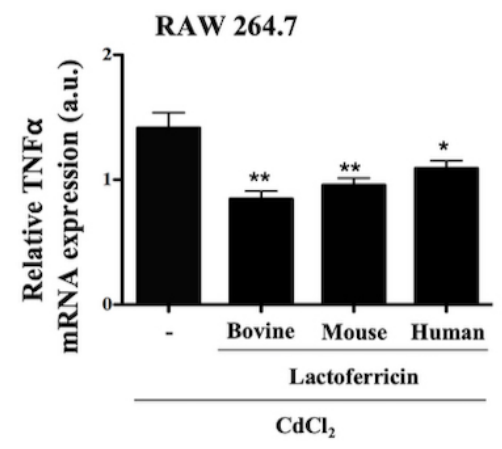

Fig. 8. Lactoferricin peptides decrease cadmium-induced TNF- $\alpha$ production in macrophages. (A) THP- 1 cells and (B) RAW 264.7 cells were treated with $10 \mu \mathrm{M} \mathrm{CdCl}_{2}$ alone or in combination with $5 \mu \mathrm{M}$ bovine, mouse, or human lactoferricin, for $24 \mathrm{~h}$. Supernatants were collected and ELISA was used to determine relative levels of TNF- $\alpha$ production. (C) RNA was isolated from RAW 264.7 cells treated with $10 \mu \mathrm{M} \mathrm{CdCl}_{2}$ alone or in combination with $5 \mu \mathrm{M}$ bovine, mouse, or human lactoferricin, for $4 \mathrm{~h}$, cDNA was synthesized and q-PCR was performed to determine relative levels of TNF- $\alpha$ expression normalized to untreated control. Data show are the mean of 3-5 independent experiments \pm SEM. ELISA data was normalized to untreated controls: 108 $\mathrm{pg} / \mathrm{mL}$ and $118 \mathrm{pg} / \mathrm{mL}$, respectively; * denotes $p<0.05$ compared to LPS control as determined by ANOVA with the Dunnett's multiple comparisons post test; a.u. denotes arbitrary units. 
expression profile mirrored that of cytokine production in THP-1 cells; however, this was not the case for RAW 264.7 cells. Possible reasons for this discrepancy include regulation of LPS-induced TNF- $\alpha$ on multiple levels (posttranscriptional and/or translational modifications) or a kinetics issue with lactoferricin administration (use of a different time point for cytokine production).

NO is another important pro-inflammatory mediator produced by LPS-stimulated macrophages [30,31]. As with pro-inflammatory cytokine production, lactoferricin peptides decreased LPS-induced NO production in RAW 264.7 cells and BMDMs, with bovine and human lactoferricin having the greatest inhibitory effect. iNOS expression experiments demonstrated the capacity for lactoferricin peptides to downregulate another prominent pro-inflammatory marker in macrophages. Lactoferricin peptides affected the expression of iNOS, the enzyme that synthesizes NO via the conversion of arginine to citrulline in the cytoplasm [30], in a manner that mirrored the effect on NO production in RAW 264.7 cells and BMDMs. NO production in THP-1 cells was not investigated as previous studies have shown that these cells do not produce detectable levels of NO when stimulated with LPS or other microbial products [32,33].

There are several possible reasons for the differential effects of lactoferricin peptides from different species on pro-inflammatory mediator production by macrophages [34-37]. As seen in Table 1, the amino acid composition between lactoferricin peptides from bovine, mouse, and human sources contain subtle differences. The functional diversity that exists between each of these peptides could lie in their different amino acid compositions. Although no studies have directly looked at the structurefunction relationship between these three particular peptides in an immunomodulatory context, several previous investigations have highlighted the importance of peptide structure in host defense and antimicrobial effects of AMPs [38-40]. The secondary structure of bovine lactoferricin and human lactoferricin in aqueous solution is an antiparallel beta sheet [35-37]. It is reasonable to assume that mouse lactoferricin also assumes an antiparallel beta sheet in an aqueous environment. Among the three lactoferricin peptides investigated in the current study, bovine lactoferricin is known to have the greatest antimicrobial activity [22]. Since bovine lactoferricin and human lactoferricin have the same secondary structure, increased antibacterial activity of bovine lactoferricin over human lactoferricin is believed to be due to different distribution of charge surrounding the hydrophobic core [34]. For example, bovine lactoferricin contains two Trp residues whereas mouse and human lactoferricincontain one Trp residue. Like other antimicrobial peptides [41], bovine lactoferricin binds to negatively charged cell surface structures [42]; however, at the present time the specific structures that lactoferricin binds are not known, nor is it known for certain how lactoferricin peptides are internalized by macrophages, al- though it is likely via endocytosis of lactoferricin-bound and crosslinked structures.

The most prominent of the inflammatory signaling pathways induced by LPS is the $\mathrm{I} \kappa \mathrm{B} \alpha-\mathrm{NF}-\kappa \mathrm{B}$ pathway [4]. In this study, bovine lactoferricin transiently inhibited $\mathrm{I} \kappa \mathrm{B} \alpha$ phosphorylation in LPS-stimulated macrophages, with the greatest suppressive effect seen $1 \mathrm{~h}$ post-treatment. All three lactoferricin peptides significantly decreased phospho-I $\kappa \mathrm{B} \alpha$ expression in LPS-stimulated RAW 264.7 and THP-1 cells. Peptide treatment in the absence of LPS stimulation did not affect $\mathrm{I} \kappa \mathrm{B} \alpha$ signaling. Previous studies of other AMPs have revealed similar downregulation of phospho-I $\kappa \mathrm{B} \alpha$ in macrophage cell lines [43-45]. As phospho- $\mathrm{I} \kappa \mathrm{B} \alpha$ is indicative of a pro-inflammatory response due to the movement of NF- $\kappa \mathrm{B}$ into the nucleus, NF- $\kappa \mathrm{B}$ nuclear translocation was then monitored in LPS-stimulated macrophages. The inhibitory effect of lactoferricin peptides on nuclear translocation of p65 is consistent with the inhibition of $\mathrm{I} \kappa \mathrm{B} \alpha$ phosphorylation by these peptides, which was approximately the same for bovine, human and mouse lactoferricin peptides. These observations are consistent with other studies demonstrating AMP regulation of inflammatory responses via inhibition of NF- $\kappa \mathrm{B}$ nuclear translocation [46-48].

Past studies implicate MAPK signaling in AMPmediated immunomodulation and the selective manner in which these peptides can induce a response [49-52]. The present study shows that LPS-induced activation of ERK$1 / 2$ signaling is decreased in lactoferricin-treated RAW 264.7 and THP-1 cells. ERK-1/2 induces further downstream signaling components such as c-Jun and c-Fos subunits of the AP-1 transcription factor family in macrophages [53-55]. Lactoferricin peptides also decreased expression of phosphorylated c-Jun in macrophages. This is consistent with the anti-inflammatory role of lactoferricin peptides as AP-1, like NF- $\kappa \mathrm{B}$, regulates the transcription of pro-inflammatory mediators when macrophages are stimulated by LPS [56,57].

$\mathrm{CdCl}_{2}$, a heavy metal carcinogen, induces mitochondrial-generated ROS in macrophages, which stimulates synthesis of pro-inflammatory cytokines such as TNF- $\alpha$. AMPs such as human and mouse-derived cathelicidins show antioxidant properties by reducing harmful oxidative burden, similar to the effect of glutathione [47,58]. Given that $\mathrm{CdCl}_{2}$ leads to the production of ROS, which induces TNF- $\alpha$, and all three peptides were able to downregulate $\mathrm{CdCl}_{2}$-induced TNF- $\alpha$ production in mouse and human macrophages, it is possible that the lactoferricin peptides act as antioxidants. One study demonstrates that the number of disulfide bridges and cysteine residues correlate to the overall antioxidant effect of some AMPs [59]. Although each lactoferricin peptide decreased $\mathrm{CdCl}_{2}$ induced TNF- $\alpha$ production in macrophages, it is unlikely to involve disulfide bridges since the lactoferricins used in this study had a linear rather than a cyclic configuration. 


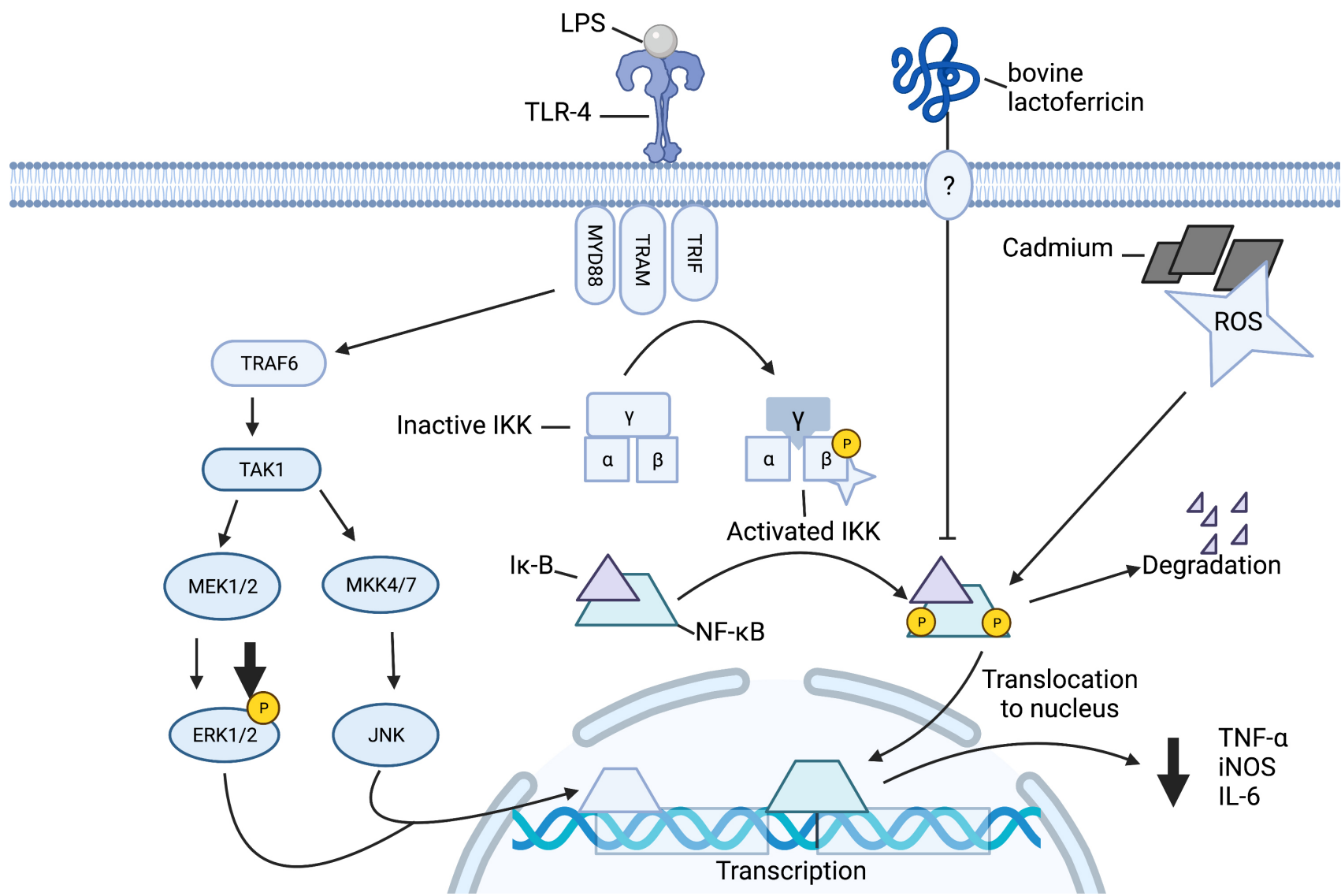

Fig. 9. Schematic of outlined anti-inflammatory effects of lactoferricin in macrophages. Lactoferricin peptides inhibit LPS-induced phosphorylation of $\mathrm{I} \kappa \mathrm{B} \alpha$ and nuclear translocation of $\mathrm{NF}-\kappa \mathrm{B}$. This subsequently inhibits the synthesis and release of proinflammatory mediators TNF- $\alpha$, IL-6, and nitric oxide. Lactoferricin peptides prevent the cadmium-induced production of TNF- $\alpha$. Lactoferricin decreases LPS-induced phosphorylation of ERK and c-Jun. Image created with biorender.com.

A contributing factor to the decrease in proinflammatory cytokine production by macrophages in the presence of lactoferricin peptides is the ability of positively charged lactoferricin to bind negatively charged LPS, thereby inhibiting endotoxin binding to TLR-4. Other studies have highlighted the importance of endotoxin binding of AMPs to inhibit inflammation $[43,60]$; however, given the selective manner in which lactoferricin targets cell signaling and its ability to decrease $\mathrm{CdCl}_{2}$-induced TNF- $\alpha$ production, it is likely that lactoferricin exerts its anti-inflammatory effect by a mechanism other than simply binding to LPS and preventing TLR-4 stimulation.

In future studies it will be important to determine whether these lactoferricin peptides have an antiinflammatory effect in animal models. The carrageenanair pouch model would be appropriate to gain insight into the potential effects of lactoferricin peptides in an acute in vivo inflammatory response [61,62]. A mouse model of colitis should also be studied to determine the effects of lactoferricin in a chronic inflammatory setting [63-65]. Enhancement of the current lactoferricin peptides, specifically bovine lactoferricin, through synthetic alteration of their amino acid sequence may lead to a peptide that is more potent as an immune regulator.

\section{Conclusions}

Inflammation is a complicated process consisting of pro-inflammatory and anti-inflammatory components that allow for an appropriate response to microbial pathogens and other insults without causing excessive tissue damage. Proper inflammation results in eradication of the source of stimulation, the cleanup of pathogenic and cellular debris, and repair of tissue damage in order to return to homeostasis. When these tightly regulated mechanisms fail, inflammation persists and can become destructive to the host. To circumvent the development of chronic inflammation or address an already existing inflammatory condition, immune regulators are required. Regulators that target a plethora of pro-inflammatory mediators benefit the host and may offer a protective effect in a wide variety of inflammatory diseases such as sepsis and colitis. Such regulators can include certain AMPs, which offer great potential as therapeutic agents owing to their relatively non-toxic nature and nonmutagenic properties in eukaryotic cells. Of the three lacto- 
ferricin peptides studied, bovine lactoferricin consistently had the greatest anti-inflammatory effects in macrophages, mediated via downregulation of LPS-induced TNF- $\alpha$, IL-6, iNOS, and NO (Fig. 9).

Although there is still much to be explored, this study has shown the selective influence of species-specific lactoferricin peptides on several important macrophageassociated inflammatory processes. The lactoferricin peptides, especially of bovine origin, may therefore have therapeutic potential in the context of downregulating excessive or inappropriate inflammatory responses.

\section{Author contributions}

$\mathrm{AM}$ and $\mathrm{DH}$ designed the research study. AM performed the research. $\mathrm{DH}$ and $\mathrm{MC}$ provided help and advice on protocols. AM, RC, DH, and MC analyzed the data. AM and $\mathrm{RC}$ made the summary figure. $\mathrm{AM}, \mathrm{RC}$, and $\mathrm{MC}$ wrote the manuscript. All authors contributed to editorial changes in the manuscript. All authors read and approved the final manuscript.

\section{Ethics approval and consent to participate}

Ethics approval for animal use to collect bone marrow derived macrophages (approval number 16-113) was obtained from the Dalhousie University Committee on Laboratory Animals.

\section{Acknowledgment}

THP-1 human monocytic-like cells were kindly provided by Brent Johnston (Dalhousie University, Halifax, NS).

\section{Funding}

This research was funded by a NSERC Discovery Grant (D.H., RGPIN2017-05339)) and the Acadia University Research Fund (M.C.).

\section{Conflict of interest}

The authors declare no conflict of interest. MC is serving as the guest editor of this journal. We declare that MC had no involvement in the peer review of this article and has no access to information regarding its peer review. Full responsibility for the editorial process for this article was delegated to GP.

\section{References}

[1] Shapouri-Moghaddam A, Mohammadian S, Vazini H, Taghadosi M, Esmaeili S, Mardani F, et al. Macrophage plasticity, polarization, and function in health and disease. Journal of Cellular Physiology. 2018; 233: 6425-6440.

[2] Rao P, Hayden MS, Long M, Scott ML, West AP, Zhang D, et al. $\mathrm{I} \kappa \mathrm{B} \beta$ acts to both inhibit and activate gene expression at different stages of the inflammatory response. Nature. 2010; 466: 11151119.

[3] Cargnello M, Roux PP. Activation and function of the MAPKs and their substrates, the MAPK-activated protein kinases. Microbiology and Molecular Biology Reviews. 2011; 75: 50-83.

[4] Zhou D, Huang C, Lin Z, Zhan S, Kong L, Fang C, et al. Macrophage polarization and function with emphasis on the evolving roles of coordinated regulation of cellular signaling pathways. Cellular Signalling. 2014; 26: 192-197.

[5] Ortega-Gómez A, Perretti M, Soehnlein O. Resolution of inflammation: an integrated view. EMBO Molecular Medicine. 2013; 5: 661-674.

[6] Koh TJ, DiPietro LA. Inflammation and wound healing: the role of the macrophage. Expert Reviews in Molecular Medicine. 2011; 13: e23.

[7] Roberts-Thomson IC, Fon J, Uylaki W, Cummins AG, Barry S. Cells, cytokines and inflammatory bowel disease: a clinical perspective. Expert Review of Gastroenterology \& Hepatology. 2011; 5: 703-716.

[8] Dutta P, Sahu RK, Dey T, Lahkar MD, Manna P, Kalita J. Beneficial role of insect-derived bioactive components against inflammation and its associated complications (colitis and arthritis) and cancer. Chemico-Biological Interactions. 2019; 313: 108824.

[9] Lambert LA, Perri H, Halbrooks PJ, Mason AB. Evolution of the transferrin family: conservation of residues associated with iron and anion binding. Comparative Biochemistry and Physiology Part B: Biochemistry and Molecular Biology. 2005; 142: 129141.

[10] Actor J, Hwang S, Kruzel M. Lactoferrin as a natural immune modulator. Current Pharmaceutical Design. 2009; 15: 1956 1973.

[11] Querinjean P, Masson PL, Heremans JF. Molecular weight, single-chain structure and amino acid composition of human lactoferrin. European Journal of Biochemistry. 1971; 20: 420425.

[12] Wang B, Timilsena YP, Blanch E, Adhikari B. Lactoferrin: Structure, function, denaturation and digestion. Critical Reviews in Food Science and Nutrition. 2019; 59: 580-596.

[13] Esaguy N, Aguas AP, Silva MT. High-resolution localization of lactoferrin in human neutrophils: labeling of secondary granules and cell heterogeneity. Journal of Leukocyte Biology. 1989; 46: $51-62$.

[14] Kruzel ML, Actor JK, Radak Z, Bacsi A, Saavedra-Molina A, Boldogh I. Lactoferrin decreases LPS-induced mitochondrial dysfunction in cultured cells and in animal endotoxemia model. Innate Immunity. 2010; 16: 67-79.

[15] Rosa L, Cutone A, Lepanto MS, Paesano R, Valenti P. Lactoferrin: a natural glycoprotein involved in iron and inflammatory homeostasis. International Journal of Molecular Sciences. 2018; 18: E1985.

[16] Håversen L, Ohlsson BG, Hahn-Zoric M, Hanson LÅ, MattsbyBaltzer I. Lactoferrin down-regulates the LPS-induced cytokine production in monocytic cells via NF- $\kappa$ B. Cellular Immunology. 2002; 220: 83-95.

[17] Håversen LA, Baltzer L, Dolphin G, Hanson LÅ, MattsbyBaltzer I. Anti-inflammatory activities of human lactoferrin in acute dextran sulphate-induced colitis in mice. Scandinavian Journal of Immunology. 2003; 57: 2-10.

[18] Yan D, Kc R, Chen D, Xiao G, Im H. Bovine lactoferricininduced anti-inflammation is, in part, via up-regulation of interleukin-11 by secondary activation of STAT3 in human articular cartilage. The Journal of Biological Chemistry. 2013; 288: 31655-31669.

[19] Kim J, Ellman MB, Yan D, An HS, Kc R, Li X, et al. Lactoferricin mediates anti-inflammatory and anti-catabolic effects via inhibition of IL-1 and LPS activity in the intervertebral disc. Journal of Cellular Physiology. 2013; 228: 1884-1896.

[20] Mattsby-Baltzer I, Roseanu A, Motas C, Elverfors J, Engberg I, Hanson LA. Lactoferrin or a fragment thereof inhibits the 
endotoxin-induced interleukin-6 response in human monocytic cells. Pediatric Research. 1996; 40: 257-262.

[21] Yan D, Chen D, Shen J, Xiao G, van Wijnen AJ, Im HJ. Bovine lactoferricin, an antimicrobial peptide, is anti-inflammatory and anti-catabolic in human articular cartilage and synovium. Journal of Cellular Physiology. 2013; 228: 447-456.

[22] Vorland LH, Ulvatne H, Andersen J, Haukland H, Rekdal O, Svendsen JS, et al. Lactoferricin of bovine origin is more active than lactoferricins of human, murine and caprine origin. Scandinavian Journal of Infectious Diseases. 1998; 30: 513-517.

[23] van der Does AM, Hensbergen PJ, Bogaards SJ, Cansoy M, Deelder AM, van Leeuwen HC, et al. The human lactoferrinderived peptide hLF1-11 exerts immunomodulatory effects by specific inhibition of myeloperoxidase activity. Journal of Immunology. 2012; 188: 5012-5019.

[24] Bowdish DME, Davidson DJ, Scott MG, Hancock REW. Immunomodulatory activities of small host defense peptides. Antimicrobial Agents and Chemotherapy. 2005; 49: 1727-1732.

[25] Wong JH, Ye XJ, Ng TB. Cathelicidins: peptides with antimicrobial, immunomodulatory, anti-inflammatory, angiogenic, anticancer and procancer activities. Current Protein Peptide Science. 2013; 14: 504-514.

[26] Yang D, Chen Q, Schmidt AP, Anderson GM, Wang JM, Wooters J, et al. LL-37, the neutrophil granule-and epithelial cellderived cathelicidin, utilizes formyl peptide receptor-Like 1 (Fprl1) as a receptor to chemoattract human peripheral blood neutrophils, monocytes, and T Cells. Journal of Experimental Medicine. 2000; 192: 1069-1074.

[27] Niyonsaba F, Someya A, Hirata M, Ogawa H, Nagaoka I. Evaluation of the effects of peptide antibiotics human beta-defensins1/-2 and LL-37 on histamine release and prostaglandin $\mathrm{D}(2)$ production from mast cells. European Journal of Immunology. 2001; 31: 1066-1075.

[28] Tavano R, Segat D, Gobbo M, Papini E. The honeybee antimicrobial peptide apidaecin differentially immunomodulates human macrophages, monocytes and dendritic cells. Journal of Innate Immunity. 2011; 3: 614-622.

[29] Guillén C, McInnes IB, Kruger H, Brock JH. Iron, lactoferrin and iron regulatory protein activity in the synovium; relative importance of iron loading and the inflammatory response. Annals of the Rheumatic Diseases. 1998; 57: 309-314.

[30] Aktan F. INOS-mediated nitric oxide production and its regulation. Life Sciences. 2004; 75: 639-653.

[31] Isaksson R, Casselbrant A, Elebring E, Hallberg M, Larhed M, Fändriks L. Direct stimulation of angiotensin II type 2 receptor reduces nitric oxide production in lipopolysaccharide treated mouse macrophages. European Journal of Pharmacology. 2020; 868: 172855.

[32] Weinberg JB. Nitric oxide production and nitric oxide synthase type 2 expression by human mononuclear phagocytes: a review. Molecular Medicine. 1998; 4: 557-591.

[33] Weinberg JB, Misukonis M, Shami P, Mason S, Sauls D, Dittman W, et al. Human mononuclear phagocyte inducible nitric oxide synthase (iNOS): analysis of iNOS mRNA, iNOS protein, biopterin, and nitric oxide production by blood monocytes and peritoneal macrophages. Blood. 1995; 86: 1184-1195.

[34] Farnaud S, Patel A, Odell EW, Evans RW. Variation in antimicrobial activity of lactoferricin-derived peptides explained by structure modelling. FEMS Microbiology Letters. 2004; 238: 221-226.

[35] Hwang PM, Zhou N, Shan X, Arrowsmith CH, Vogel HJ. Threedimensional solution structure of lactoferricin B, an antimicrobial peptide derived from bovine lactoferrin. Biochemistry. 1998; 37: 4288-4298.

[36] Chapple DS, Hussain R, Joannou CL, Hancock REW, Odell E, Evans RW, et al. Structure and association of human lactofer- rin peptides with Escherichia coli lipopolysaccharide. Antimicrobial Agents and Chemotherapy. 2004; 48: 2190-2198.

[37] Hunter HN, Demcoe AR, Jenssen H, Gutteberg TJ, Vogel HJ. Human lactoferricin is partially folded in aqueous solution and is better stabilized in a membrane mimetic solvent. Antimicrobial Agents and Chemotherapy. 2005; 49: 3387-3395.

[38] Bulet P, Hetru C, Dimarcq JL, Hoffmann D. Antimicrobial peptides in insects; structure and function. Developmental and Comparative Immunology. 1999; 23: 329-344.

[39] Takahashi H, Palermo EF, Yasuhara K, Caputo GA, Kuroda $\mathrm{K}$. Molecular design, structures, and activity of antimicrobial peptide-mimetic polymers. Macromolecular Bioscience. 2013; 13: $1285-1299$.

[40] Mattei B, Miranda A, Perez KR, Riske KA. Structure-activity relationship of the antimicrobial peptide gomesin: the role of peptide hydrophobicity in its interaction with model membranes. Langmuir: the ACS Journal of Surfaces and Colloids. 2014; 30: 3513-3521.

[41] Hilchie AL, Gill EE, Coombs MRP, Falsafi R, Hancock REW, Hoskin DW. MDA-MB-231 breast cancer cells resistant to pleurocidin-family lytic peptides are chemosensitive and exhibit reduced tumor-forming capacity. Biomolecules. 2020; 10: E1220.

[42] Mader JS, Smyth D, Marshall J, Hoskin DW. Bovine lactoferricin inhibits basic fibroblast growth factor- and vascular endothelial growth factor165-induced angiogenesis by competing for heparin-like binding sites on endothelial cells. the American Journal of Pathology. 2006; 169: 1753-1766.

[43] Scott A, Weldon S, Buchanan PJ, Schock B, Ernst RK, McAuley $\mathrm{DF}$, et al. Evaluation of the ability of LL-37 to neutralise LPS in vitro and ex vivo. PLoS ONE. 2011; 6: e26525.

[44] Hasan M, Ruksznis C, Wang Y, Leifer CA. Antimicrobial peptide inhibits poly(I:C) induced immune responses. Journal of Immunology. 2011; 187: 5653-5659.

[45] Gao Y, Lecker S, Post MJ, Hietaranta AJ, Li J, Volk R, et al. Inhibition of ubiquitin-proteasome pathway-mediated iкB $\alpha$ degradation by a naturally occurring antibacterial peptide. Journal of Clinical Investigation. 2000; 106: 439-448.

[46] Nam HY, Ahn E, Kim HJ, Lim Y, Lee CB, Lee KY, et al. Diesel exhaust particles increase IL- $1 \beta$-induced human $\beta$-defensin expression via NF- $\mathrm{kB}$-mediated pathway in human lung epithelial cells. Particle and Fibre Toxicology. 2006; 3: 9.

[47] Brown KL, Poon GFT, Birkenhead D, Pena OM, Falsafi R, Dahlgren C, et al. Host defense peptide LL-37 selectively reduces proinflammatory macrophage responses. Journal of Immunology. 2011; 186: 5497-5505.

[48] Mookherjee N, Brown KL, Bowdish DME, Doria S, Falsafi R, Hokamp K, et al. Modulation of the TLR-mediated inflammatory response by the endogenous human host defense peptide LL-37. Journal of Immunology. 2006; 176: 2455-2464.

[49] Niyonsaba F, Ushio $H$, Hara $M$, Yokoi $H$, Tominaga $M$, Takamori K, et al. Antimicrobial peptides human $\beta$-defensins and cathelicidin LL-37 induce the secretion of a pruritogenic cytokine IL-31 by human mast cells. The Journal of Immunology. 2010; 184: 3526-3534.

[50] Jiang R, Lopez V, Kelleher SL, Lönnerdal B. Apo- and hololactoferrin are both internalized by lactoferrin receptor via clathrin-mediated endocytosis but differentially affect ERKsignaling and cell proliferation in Caco-2 cells. Journal of Cellular Physiology. 2011; 226: 3022-3031.

[51] Mookherjee N, Lippert DND, Hamill P, Falsafi R, Nijnik A, Kindrachuk $\mathrm{J}$, et al. Intracellular receptor for human host defense peptide LL-37 in monocytes. The Journal of Immunology. 2009; 183: 2688-2696.

[52] Han W, Wang W, Mohammed KA, Su Y. A-Defensins increase lung fibroblast proliferation and collagen synthesis via the $\beta$ - 
catenin signaling pathway. FEBS Journal. 2009; 276: 66036614.

[53] Deng Z, Sui G, Rosa PM, Zhao W. Radiation-induced c-Jun activation depends on MEK1-ERK1/2 signaling pathway in microglial cells. PLoS ONE. 2012; 7: e36739.

[54] Leppä S, Saffrich R, Ansorge W, Bohmann D. Differential regulation of c-Jun by ERK and JNK during PC12 cell differentiation. The EMBO Journal. 1998; 17: 4404-4413.

[55] Monje P, Hernández-Losa J, Lyons RJ, Castellone MD, Gutkind JS. Regulation of the transcriptional activity of c-Fos by ERK. a novel role for the prolyl isomerase PIN1. The Journal of Biological Chemistry. 2005; 280: 35081-35084.

[56] Karin M, Liu ZG, Zandi E. AP-1 function and regulation. Current Opinion in Cell Biology. 1997; 9: 240-246.

[57] Casals-Casas C, Álvarez E, Serra M, de la Torre C, Farrera C, Sánchez-Tilló E, et al. CREB and AP-1 activation regulates MKP-1 induction by LPS or M-CSF and their kinetics correlate with macrophage activationversusproliferation. European Journal of Immunology. 2009; 39: 1902-1913.

[58] Seil M, Kabré E, Nagant C, Vandenbranden M, Fontanils U, Marino A, et al. Regulation by CRAMP of the responses of murine peritoneal macrophages to extracellular ATP. Biochimica Et Biophysica Acta. 2010; 1798: 569-578.
[59] He W, Feng F, Huang Y, Guo H, Zhang S, Li Z, et al. Host defense peptides in skin secretions of Odorrana tiannanensis: Proof for other survival strategy of the frog than merely anti-microbial. Biochimie. 2012; 94: 649-655.

[60] Scott MG, Vreugdenhil AC, Buurman WA, Hancock RE, Gold MR. Cutting edge: cationic antimicrobial peptides block the binding of lipopolysaccharide (LPS) to LPS binding protein. Journal of Immunology. 2000; 164: 549-553.

[61] Romano M, Faggioni R, Sironi M, Sacco S, Echtenacher B, Di Santo E, et al. Carrageenan-induced acute inflammation in the mouse air pouch synovial model. Role of tumour necrosis factor. Mediators of Inflammation. 1997; 6: 32-38.

[62] Duarte DB, Vasko MR, Fehrenbacher JC. Models of inflammation: carrageenan air pouch. Current Protocols in Pharmacology. 2012; 56: 5.6.1-5.6.8.

[63] Bain CC, Mowat AM. The monocyte-macrophage axis in the intestine. Cellular Immunology. 2014; 291: 41-48.

[64] Popivanova BK, Kitamura K, Wu Y, Kondo T, Kagaya T, Kaneko S, et al. Blocking TNF- $\alpha$ in mice reduces colorectal carcinogenesis associated with chronic colitis. The Journal of Clinical Investigation. 2008; 118: 560-570.

[65] Sands BE, Kaplan GG. The role of TNF $\alpha$ in ulcerative colitis. The Journal of Clinical Pharmacology. 2007; 47: 930-941. 